\title{
The DNA methylation machinery
}

The readers, writers and erasers of methylcytosine and their regulation.

\section{Mark Morris}

\begin{abstract}
Cytosine methylation is an important epigenetic signalling mechanism that regulates gene expression. The presence of 5-methylcytosine (5-mC) at promoters is associated with gene silencing. In this chapter, we will describe our current understanding of;

i) The mechanisms and molecules involved in the addition, and maintenance, of methyl groups to cytosine bases (5-mC writers).

ii) The mechanism by which these 5-mC modifications are read resulting in changes in gene expression.

iii) The molecules and mechanisms involved in removing methyl groups from cytosine bases (5-mC erasers).
\end{abstract}




\section{DNA Methylation / Methylcytosine}

In eukaryotic cells, the addition of methyl groups $\left(\mathrm{CH}_{3}\right)$ to DNA occurs almost exclusively on cytosine bases, more specifically at cytosines that are found directly $5^{\prime}$ to a guanine forming a CpG dinucleotide (Figure $1 \mathrm{~A}$ ). Methylation occurs at the $5^{\text {th }}$ atom of the 6-atom ring (Figure 1B) resulting in the formation of 5-methylcytosine (5$\mathrm{mC}$ ). On double stranded DNA, a CpG dinucleotide on one DNA strand will bind to a complementary CpG dinucleotide on the opposite DNA strand. If a cytosine on one DNA strand is methylated then its opposite counterpart will also be methylated (Figure 1A; see Chapter 3 - Methylcytosine and its oxidised derivatives for further details). 5 -mC behaves in the same way as unmethylated cytosine; it binds to guanine in double stranded DNA (dsDNA) and acts as the complementary base for guanine during transcription (not changing the genetic function of DNA is a defining feature of an epigenetic modification).

In humans, and other mammals, most CpG dinucleotides contain methylated cytosine (5-mC) and these methylated $\mathrm{CpGs}$ are distributed sparsely throughout the genome (Ziller et al. 2013). They are found at a low frequency in gene body regions and more densely at endogenous repeats and transposable elements (Bird 2002). The presence of 5-mC in gene body regions is associated with high levels of gene transcription while, the more densely occurring $5-\mathrm{mC}$ found at transposable elements, such as LINE-1, suppresses transcription and mobility (Schulz et al. 2006). Throughout the mammalian genome CpG dinucleotides are relatively rare due to the spontaneous deamination of 5-mC to thymine (Lander et al. 2001) (Figure 2). However, unmethylated $\mathrm{CpG}$ dinucleotides are more abundant in regions called $\mathrm{CpG}$ islands. These range in size from about $300 \mathrm{bp}$ to $3 \mathrm{~kb}$ in length and can be found at the promoter region, often encompassing the first exon, of approximately 
$70 \%$ of all human genes (Figure 3). There are approximately $27,000 \mathrm{CpG}$ islands found in the non-repetitive regions of the human genome (Rollins et al. 2005; Saxonov et al. 2006; Deaton and Bird 2011).

The expression pattern of genes determines the phenotype of cells, and which genes are expressed in a cell is principally determined by two factors:

1). Gene expression is regulated by the binding of appropriate (lineage-specific) transcription factors (TFs) at the promoter region. These TFs are required to recruit RNA polymerase to the start of transcribed gene regions. The presence of cell specific transcription factors is determined during embryogenesis and is also regulated via cell signalling (Spitz and Furlong 2012).

2). For transcription factors and RNA polymerase to bind to gene promoter regions the chromatin (DNA and associated proteins) at that region must be in an uncondensed state, that is, the number of histones in that region must be low, allowing ready access to the naked DNA.

A complex network of histone modifying proteins regulates the level of chromatin condensation (see Chapter 4 - The role of nucleosomes in epigenetic gene regulation for further details). Two key regulators are histone acetyltransferases (HATs) and histone deacetylases (HDACs). HATs add acetyl groups $\left(\mathrm{CH}_{3} \mathrm{CO}(\mathrm{Ac})\right)$ while HDACs remove these from specific amino acids on histones (Verdin and Ott 2014).

The methylation status of $\mathrm{CpGs}$, and in particular $\mathrm{CpG}$ islands, determines the acetylation status of localized histones which, in turn, regulates the condensation of that region of chromatin, the accessibility of associated promoters and thus regulates gene expression. The mechanism by which this process occurs will be discussed in the next section. 


\section{Readers of methylcytosine: DNA methylation and gene expression}

The methylation status of $\mathrm{CpGs}$ can be read by three types of interacting proteins, these are 1) The methyl-CpG binding domain protein (MBD) family, 2) The Kaiso proteins and Kaiso-like proteins and 3) The UHRF proteins (Ubiquitin-like with PHD and ring finger domains). As the name suggests, the MBD family of proteins binds to regions containing double stranded methylated $\mathrm{CpG}(5-\mathrm{mCpG})$ via a conserved binding domain (Nan et al. 1993), while the Kaiso and Kaiso-like proteins bind to methylated DNA via zinc finger motifs (Prokhortchouk et al. 2001; Filion et al. 2006). Both the MDB and Kaiso/Kaiso-like proteins repress the transcription of the DNA region they bind to (Hendrich and Bird 1998; Filion et al. 2006). However, the manner in which they target DNA is slightly different; Kaiso proteins bind to two consecutive methylated $\mathrm{CpG}$ sites whereas the MBD proteins preferentially bind to single CpG dinucleotides (Daniel et al. 2002; Sasai et al. 2010). UHRF proteins do not repress transcription, they are involved in ensuring both strands of DNA maintain 5-mCpG patterns during DNA replication; UHRF proteins bind to hemimethylated DNA (DNA where a CpG cytosine is methylated on only one strand of double stranded DNA) and recruit the DNA methyltransferase DNMT1 to that location (Bostick et al. 2007; Sharif et al. 2007). See Section 3 - Writers of methylcytosine: DNA methyltransferases (DNMTs) within this chapter for further details regarding the role of DNMTs.

\subsection{Methyl-CpG binding domain proteins (MBD)}

The MDB family comprises 7 proteins; MeCP2 (methyl-CpG-binding protein 2), MBD1, MBD2, MBD3, MBD4, MBD5 and MBD6 (Hendrich and Bird 1998; Baymaz et al. 2014). All of these proteins bind directly to methylated DNA (via a $60-85$ amino acid (aa) MBD domain). MeCP2, MBD1 and MBD2 also bind to transcriptional 
repressors via a transcriptional repression domain (TRD) (Wolffe et al. 1999; Boeke et al. 2000), while MBD3 interacts with transcriptional repressor proteins via a Cterminal coiled-coiled domain (Hendrich and Bird 1998) (Figure 4). MDB proteins can bind to different yet overlapping partner proteins via their TRD. A key family of transcriptional repressors is the histone deacetylases (HDAC1, 2 and 3). These HDACs can bind to MeCP2 and MBD1-3 ( $\mathrm{Ng}$ et al. 1999; Kokura et al. 2001; Saito and Ishikawa 2002; Shyh-Chang et al. 2013; Lyst et al. 2013). By bringing HDACs and other histone-modifying molecules to regions of methylated DNA, MBD proteins can direct the formation of heterochromatin. Heterochromatin consists of highly condensed chromatin that is often inaccessible to the transcriptional machinery and associated with low levels of acetylation (due to the activity of HDACs bound to MBD-proteins) (Taddei et al. 2001) at histone $\mathrm{H} 3$ on lysine residues 9, 14 and 18, and histone H4 on lysine residue 16 (Verdin and Ott 2014). In contrast, these regions often contain high levels of methyl groups on specific histones, such as histone $\mathrm{H} 3$ methylation on lysine 9 (Fuks et al. 2003)). MeCP2, MBD1 and MBD2 bind to histone methyltransferase proteins (SUV39H1, SETDB1 and PRMT5) (Lunyak et al. 2002; Fujita et al. 2003; Sarraf and Stancheva 2004; Le Guezennec et al. 2006) which facilitate the methylation of local histones (for further information regarding MDBs and their binding partners see Du et al. 2015). Heterochromatin is initiated by the juxtaposition of individual nucleosomes into dense nucleosome arrays by nucleosome remodeling complexes (see Chapter 4 - The role of nucleosomes in epigenetic gene regulation for further details). Two of these complexes are NuRD/Mi2 (a nucleosome remodeling complex with histone deacetylase activity (conferred by HDAC1 and HDAC2) (Xue et al. 1998) and the SWI/SNF ATP-dependent chromatin 
remodeling complex BAF (for a general review of SWI/SNF complexes see Kadoch and Crabtree 2015).

MeCP2 binds to the BAF complex by the BRM (also known as SMARCA2) subunit (Harikrishnan et al. 2005) and MBD2 and 3 bind to the NuRD/Mi-2 complex (Ramírez et al. 2012; Baubec et al. 2013). Thus, the recognition of methylated DNA by MeCP2 and MBD1 and 3 results in modification of local histones (deacetylation and methylation). This facilitates the binding of nucleosome-remodeling protein complexes (also directed to that location by MBD proteins) and the remodeling of nucleosomes to reduce accessibility. This decrease in accessibility closes access to the local DNA for transcription factors and RNA polymerase, resulting in transcriptional silencing.

MBD4 does not play a significant role in transcription repression. Rather, it contains a glycosylase domain that facilitates mismatch repair $(\mathrm{mC}>\mathrm{T}$ or $\mathrm{C}>\mathrm{U})$ at $\mathrm{CpG}$ dinucleotides (Hendrich et al. 1999; Petronzelli et al. 2000). Both MBD5 and 6 remain to be fully characterized; despite containing MBD domains, there is no

evidence that they bind to methylated DNA (Laget et al. 2010). However, they do bind to the human polycomb deubiquitinase complex (PR-DUB) which removes ubiquitin from Histone H2AK119 (Baymaz et al. 2014).

\section{Writers of methylcytosine: DNA methyltransferases (DNMTs)}

Humans possess five DNA methyltransferase enzymes (DNMTs); DNMT1, DNMT2, DNMT3A, DNMT3B and DNMT3L. Of these, DNMT1, DNMT3A and DNMT3B add methyl groups to cytosine bases at CpG dinucleotides within DNA (Lyko 2017) using S-adenosylmethionine as the methyl donor (Du et al. 2016). DNMT1, DNMT3A and 
DNMT3B contain a C-terminal catalytic domain responsible for methylating CpGs and varying N-terminal regulatory domains (Denis et al. 2011) (Figure 5). Although DNMT2 and DNMT3L share high levels of conservation with the other DNMTs, they do not possess catalytic domains capable of methylating CpG dinucleotides and have smaller N-terminal regulatory domains (Aapola et al. 2000; Dong et al. 2001). DNMT2 methylates a small subset of tRNAs (Legrand et al. 2017) and DNMT3L can bind to DNMT3A to form heterotetramers (2 DNMT3A molecules and 2 DNMT3L molecules). These heterotetramers have increased catalytic activity compared to DNMT3A monomers (Jia et al. 2007).

\subsection{The function of DNMTs: maintenance methylation}

As described in section 2 of this chapter, many of the readers of DNA methylation only recognise fully methylated double stranded $\mathrm{CpG}$ dinucleotides in which the cytosine bases on both strands must be methylated. To maintain methylation during DNA replication, each newly synthesised daughter DNA strand must be methylated using the original methylated DNA strand as a template. This maintenance methylation is the principal role of DNMT1 (Bestor et al. 1988; Li et al. 1992). DNMT1 is directed to the replication fork during $S$ phase by binding to HDAC2 and DNA methyltransferase-associated protein 1 (DMAP1) (Rountree et al. 2000). DNMT1 also binds to PCNA (proliferating cell nuclear antigen) (Chuang et al. 1997) and DNA directly at the replication fork (Suetake et al. 2006). Once at the replication fork, DNMT1 recognises hemimethylated DNA by directly interacting with the UHRF proteins (Bostick et al. 2007; Sharif et al. 2007; Berkyurek et al. 2014). Once DNMT1 is in position, its catalytic domain covers the hemimethylated DNA region and both the selection of the cytosine for methylation and the process of methylation occurs 
within the catalytic domain (Song et al. 2012; Bashtrykov et al. 2012). In addition to this maintenance methylation, DNMT1 (and DNMT3B) can facilitate de novo methylation of promoter regions via interactions with MBD3-NuRD/Mi-2 complexes (Cai et al. 2014).

\subsection{The function of DNMTs: establishment of DNA methylation}

Appropriate DNA methylation in mammalian germ cells is essential for fertility and the viability of the resulting embryo (Messerschmidt et al. 2014). Primordial oocyte cells undergo genome-wide demethylation (Seisenberger et al. 2012), then the growing oocytes (not yet fertilised) proceed to develop complex, organised DNA methylation patterns. During this period $\mathrm{CpG}$ islands associated with maternally imprinted genes are also methylated. This de novo methylation is carried out by DNMT3/DNMT3L complexes (Okano et al. 1998; Okano et al. 1999) and appears to be associated with histone modifications such as histone 3 lysine 36 trimethylation (H3K36me3) that are associated with transcriptional activity, suggesting that transcriptional activity is required in the non-dividing oocyte prior to gene silencing (Smallwood et al. 2011; Stewart et al. 2015). However, the precise timing and manner in which these enzymes are directed to specific regions of the oocyte genome remains to be fully clarified. Mammalian sperm cells also have distinct patterns of DNA methylation. However, unlike oocytes, as sperm progenitor cells undergo repeated mitoses at the onset of puberty the activity of DNMT1 is required to maintain the pattern of methylation (Marques et al. 2011). Shortly after fertilisation the embryonic genome undergoes a wave of demethylation (Sasaki and Matsui 2008) (see Section 4 in this chapter for mechanistic details of DNA demethylation). The unmethylated DNA of the embryo is then re-methylated by DNMT3/DNMT3L 
complexes. DNMT3/DNMT3L methylate DNA in a non-selective manner, they have a preference for $\mathrm{CpG}$ dinucleotides but can also methylate $\mathrm{CpH}(\mathrm{H}=\mathrm{A}, \mathrm{C}$ or $\mathrm{T})$ dinucleotides (Gowher and Jeltsch 2001). Recent advanced in sequencing technology has enabled the identification of frequent $\mathrm{CpH}$ methylation in embryonic stem cells and neurones (Lister et al. 2009; Ziller et al. 2011). Differences in cellspecific levels of $\mathrm{CpH}$ methylation appears to be a consequence of differential expression of DNMT3a and DNMT3b (Lee et al. 2017). The mechanism that determines which DNA sequences are de novo methylated by DNMT3/DNMT3L is unclear. However, it is known that, in addition to preferentially methylating CpG dinucleotides, this is influenced by the surrounding sequence; CpGs with purine bases on the $5^{\prime}$ flank and pyrimidines on the $3^{\prime}$ flank are preferentially methylated (Lin et al. 2002). DNMT3 binds directly to histone H3 tails (Ooi et al. 2007) and this binding allosterically activates DNMT3 resulting the methylation of DNA local to that histone (Guo et al. 2014b; Baubec et al. 2015). The presence of large modifications on $\mathrm{H} 3 \mathrm{~K} 4$ (tri-methylation or acetylation) prevents binding of DNMT3 and associated DNA methylation (Ooi et al. 2007). Genome wide-methylation studies have shown a strong correlation between the absence of $\mathrm{H} 3 \mathrm{~K} 4 \mathrm{me} 3$ and DNA methylation (Weber et al. 2007; Meissner et al. 2008) suggesting that this mechanism is important in setting global DNA methylation patterns. DNMT3 also binds to histone $\mathrm{H} 3$ when it is trimethylated at lysine $36(\mathrm{H} 3 \mathrm{~K} 36 \mathrm{me} 3)$. This histone mark is found in gene bodies and at exon-intron boundaries and correlates to transcriptionally active regions. The presence of H3K36me3 is also inversely correlated to H3K4me3 (Vakoc et al. 2006; Barski et al. 2007; Guenther et al. 2007). 


\subsection{CpG Islands}

As described previously, CpG island are $\mathrm{CpG}$-rich regions that are associated with the promoter region of approximately $70 \%$ of human genes. The majority of these CpG islands are not methylated during early embryogenesis, and are associated with a histone $\mathrm{H} 3$ modifications (H3K27me3 and H3K4me3); H3K27me3 marked regions of DNA are prone to undergo methylation during differentiation and oncogenesis (Ohm et al. 2007). The presence of transcription factors at regions of active transcription is associated with the absence of DNA methylation. This was observed more than 20 years ago (Brandeis et al. 1994; Macleod et al. 1994; Han et al. 2001) and more recently has been further validated by Genome-Wide Association Studies (GWAS) indicating that promoter region variations (and associated changes in transcription factor binding) correlated with changes in localised DNA methylation (Gutierrez-Arcelus et al. 2013). These results suggest that the cell-specific differential presence of transcription factors plays a significant role in determining the methylation status and chromatin pattern of different cell types during embryogenesis. By the blastocyst implantation stage of development the expression of DNMT3A, B and $L$ is reduced and the expression of DNMT1 is increased (Huntriss et al. 2004; Vassena et al. 2005; Uysal et al. 2015). At this point cell type-specific methylation patterns have been set and are now maintained through repeated rounds of mitosis.

\section{Erasers of methylcytosine}

There are two main processes that lead to the demethylation of DNA; the first is passive demethylation, where the absence or low expression of the maintenance methyltransferase DNMT1 results in a dilution of DNA methylation marks as the 
genome replicates. This results in regions of hemimethylated and, ultimately, unmethylated DNA.

As mentioned in section 3.2, methylation marks are removed in a wave of DNA demethylation after fertilisation. Both the paternal and maternal component of the zygote genome are demethylated via passive dilution through DNA replication and an active process involving the TET (Ten-Eleven Translocation) proteins (Guo et al. 2014a). TET proteins were first identified as being components of a fusion protein, found in acute myeloid leukemia, due to a translocation between chromosomes ten and eleven (Lorsbach et al. 2003). The TET family of proteins (TET 1, 2 and 3) are oxyginases that catalyse the demethylation of $5 \mathrm{mC}$; firstly $5 \mathrm{mC}$ is converted to 5 hydroxymethylcytosine $(5 \mathrm{hmC})$, which is then converted to 5 -formylcytosine $(5 \mathrm{fC})$ and finally to 5-carboxylcytosine (5caC). All three TET enzymes are capable of catalysing each of these steps (Kriaucionis and Heintz 2009; Tahiliani et al. 2009; Ito et al. 2010; Ito et al. 2011). The resulting $5 \mathrm{fC}$ or $5 \mathrm{caC}$ is recognised by thymine DNA glycosylase (TDG) and is restored by base excision repair (BER) (He et al. 2011). TDG excised the $5 \mathrm{fC}$ or $5 \mathrm{caC}$ resulting in an abasic site that is converted to a single strand break. DNA polymerase $\beta$ (Pol $\beta$ ) then inserts a deoxycytidine monophosphate at the break and the double stranded DNA is restored by DNA ligase 3 (Weber et al. 2016). This active modification-active removal (AM-AR) is independent of DNA replication (Kohli and Zhang 2013). The $5 \mathrm{mC}$ oxidative derivative can also remain incorporated in the genome and be converted to unmethylated cytosines by replicative dilution. This can occur in the presence of DNMT1 as it does not have a high affinity for 5hmC:C, 5fC:C and 5caC:C (Hashimoto et al. 2012; Ji et al. 2014). In addition to demethylating genomes during embryogenesis, the TET proteins play important roles in determining pluripotency cell differentiation: Recent knockout 
experiments in mouse embryonic stem cells have shown that loss of TET1 or TET2 reduce the level of $5 \mathrm{hmC}$ and alter gene transcription. With unique targets being identified for each protein, the resulting gene expression changes have been suggested to influence differentiation potential of these stem cells (Koh et al. 2011; Huang et al. 2014).

\subsection{Regulation of DNA demethylation by TET enzymes}

TET protein activity requires $\alpha-K G$ and oxygen as substrates and $\mathrm{Fe}(\mathrm{II})$ as a cofactor. The availability of these molecules can influence the activity of the TET catalysed reaction (Lu et al. 2015). $\alpha-K G$ is generated in the citric acid cycle by the activity of isocitrate dehydrogenase (IDH1, 2, 3). Upregulation of IDH results in the production of excess $\alpha-K G$ and an associated increase of $5 \mathrm{hmC}$ throughout the genome, whereas loss of function mutations in IDH result in reduced $\alpha-K G$ production and are associated with increased levels of genomic methylation (Losman and Kaelin 2013). Similarly, fumarate and succinate can accumulate in tumour cells following disruption of the citric acid cycle and these molecules compete with $\alpha-K G$, resulting in reduced TET activity (Laukka et al. 2016).

TET proteins are found to localise preferentially to CpG islands and transcriptionally active promoters, this is facilitated in part, by DNA binding domains that preferentially bind $\mathrm{CpG}$ rich regions, and in part due to interactions with other binding partners such as the pluripotency factor NANOG (Costa et al. 2013) and Polycomb repressive complex 2 (PRC2) (Neri et al. 2013). 
In certain tissues the levels of $5 \mathrm{mC}$ oxidative derivatives are relatively high, suggesting that they have functional roles beyond being intermediates for demethylation. Moreover, the balance between the activity of DNA methyltransferases and the demethylation machinery is delicate, and when an imbalance occurs, either during development or in somatic cells, disease can result. Further details on $5 \mathrm{mC}$ oxidation, as well as examples of mutations in the methylation machinery that result in disease, are discussed in Chapter 3 Methylcytosine and its oxidised derivatives.

\section{Conclusion}

In the mammalian cell, there is a delicate balance being held between DNA modifying enzymes, the writers and erasers of methylcytosine. During embryogenesis the timing and molecular positioning of demethylation and then remethylation is orchestrated with incredible precision to facilitate appropriate differentiation. Once tissue differentiation has occurred these epigenetic marks are maintained or, in some tissue types, progressively change. In many ways, these simple markers are relatively easy to understand and molecular techniques allow us to analyse them at ever increasing speed and throughput. However, there is still much to discover, in particular how these molecules are regulated and interact with each other and how DNA modifying and binding molecules interact with histone modifying and binding molecules to determine chromatin structure and cell specific gene expression. Discovering the mode of these interactions will be important for future molecular medicine. 


\section{Figure Legends}

Figure 1. 5-methylcytosine occurs primarily within the context of a CpG dinucleotide. A, Shown are two complementary (base-paired) antiparallel strands of DNA containing a CpG dinucleotide, where 'p' represents the sugar-phosphate backbone linked through phosphodiester bonds (shaded grey). In this example, the molecule contains 5-methylcytosine (dashed circled). Note that the sequence is palindromic (CG:GC), that each strand is read in the $5^{\prime}$ to $3^{\prime}$ direction and that 5methylcytosine is present on both strands. B, Methylation of cytosine occurs at the $5^{\text {th }}$ atom of the 6 -atom ring resulting in the formation of 5-methylcytosine.

Figure 2. Spontaneous deamination of 5-methylcytosine to thymine as a source of $\mathbf{C}$ to $\mathbf{T}$ transitions. The pyrimidine bases cytosine and thymine differ by virtue of a primary amine group (cytosine) or a carbonyl group (thymine) at the $4^{\text {th }}$ carbon. Methylation of cytosine at the $5^{\text {th }}$ atom of the 6 -atom ring followed by deamination results in thymine.

Figure 3. CpG and methyl-CpG distribution. CpG dinucleotides are more abundant in regions called $\mathrm{CpG}$ islands, which are found in the promoter regions of a subset of genes and in non-genic sequences such as repeat elements. In normal cells, the promoter regions of expressed genes are usually unmethylated (white circles), though it should be noted that an absence of methylation does not imply the gene is actually expressed. Conversely, methylation within a gene promoter region is not conducive to gene expression. CpG dinucleotides within the body of highly expressed genes are usually methylated, whereas those in weakly or non-expressed 
genes are often unmethylated. CpG dinucleotides in repeat elements and transposable elements are methylated to ensure they remain transcriptionally silent.

Figure 4. The conserved functional domains of the methyl-binding domain proteins MeCP2, MBD1, MBD2, MBD3, MBD4, MBD5 and MBD6. All members of the methyl-binding domain family of proteins contain a methyl-CpG-binding domain (MBD) that facilitates binding to methylated DNA. MBD1 also contains CxxC domains that enables the binding of unmethylated $\mathrm{CpG}$ regions. MeCP2, MBD1 and MBD2 contain transcription repression domains (TDR) these regions bind to proteins that confer transcriptional repression, most notably HDAC1, 2, and 3. MBD2 and MBD3 contain coiled-coiled domains (CC) that facilitate transcriptional repression through the binding of HDACs and other histone modifying proteins such as NuRD/Mi-2. MBD4 does not contain domains involved in transcriptional repression, it possesses a glycosylase domain that facilitates mismatch repair at CpG dinucleotides. Protein size is given in amino acids (aa) and represents the size of the human homologue.

Figure 5. The conserved functional domains of the DNA methyltransferase proteins DNMT1, DNMT2, DNMT3A, DNMT3B and DNMT3L. All members of the

DNMT family share a conserved C-terminal catalytic methyltransferase domain (MTase). DNMT1 contains several conserved $\mathrm{N}$-terminal regions including the DNA methyltransferase associated protein 1 interacting domain (DMAPD) that interact with the transcriptional repressor DMAP1 and also HDAC2, the PCDNA binding domain (PDB), the replication foci targeting domain (RFTD) and a CxxC domain that 
facilitates binding to unmethylated DNA. DNMT3A and DNMT3B contain Pro-TrpTrp-Pro (PWWP) and ATRX-DNMT3-DNMT3L (ADD) domains, which interact with the N-terminal tails of histones. The ADD domain, which is conserved in DNMT3L, also facilitates binding to other regulatory proteins. Protein size is given in amino acids (aa) and represents the size of the human homologue.

\section{References}

Aapola U, Shibuya K, Scott HS, Ollila J, Vihinen M, Heino M, Shintani A, Kawasaki K, Minoshima S, Krohn K, Antonarakis SE, Shimizu N, Kudoh J, Peterson P (2000) Isolation and Initial Characterization of a Novel Zinc Finger Gene, DNMT3L, on 21q22.3, Related to the Cytosine-5- Methyltransferase 3 Gene Family. Genomics 65:293-298. doi: 10.1006/GENO.2000.6168

Barski A, Cuddapah S, Cui K, Roh T-Y, Schones DE, Wang Z, Wei G, Chepelev I, Zhao K, Abeysinghe SS, Stenson PD, Krawczak M, Cooper DN, Allis CD, Glover CV, Bowen JK, Gorovsky MA, An W, Kim J, Roeder RG, Bannister AJ, Schneider R, Myers FA, Thorne AW, Crane-Robinson C, Kouzarides T, Bannister AJ, Zegerman P, Partridge JF, Miska EA, Thomas JO, Allshire RC, Kouzarides T, Bernstein BE, Humphrey EL, Erlich RL, Schneider R, Bouman P, Liu JS, Kouzarides T, Schreiber SL, Bernstein BE, Kamal M, Lindblad-Toh K, Bekiranov S, Bailey DK, Huebert DJ, McMahon S, Karlsson EK, Kulbokas EJ, Gingeras TR, al. et, Bernstein BE, Mikkelsen TS, Xie X, Kamal M, Huebert DJ, 
Cuff J, Fry B, Meissner A, Wernig M, Plath K, al. et, Bernstein BE, Meissner A, Lander ES, Boyer LA, Plath K, Zeitlinger J, Brambrink T, Medeiros LA, Lee TI, Levine SS, Wernig M, Tajonar A, Ray MK, al. et, Bruce K, Myers FA, Mantouvalou E, Lefevre P, Greaves I, Bonifer C, Tremethick DJ, Thorne AW, Crane-Robinson C, Cheng J, Kapranov P, Drenkow J, Dike S, Brubaker S, Patel S, Long J, Stern D, Tammana H, Helt G, al. et, Craig JM, Bickmore WA, Crawford GE, Holt IE, Whittle J, Webb BD, Tai D, Davis S, Margulies EH, Chen Y, Bernat JA, Ginsburg D, al. et, Gaszner M, Felsenfeld G, Guillemette B, Gaudreau L, Hatton RD, Harrington LE, Luther RJ, Wakefield T, Janowski KM, Oliver JR, Lallone RL, Murphy KM, Weaver CT, Heintzman ND, Stuart RK, Hon G, Fu Y, Ching CW, Hawkins RD, Barrera LO, Calcar S Van, Qu C, Ching KA, al. et, Huang S, Litt M, Felsenfeld G, Kent WJ, Sugnet CW, Furey TS, Roskin KM, Pringle TH, Zahler AM, Haussler D, Kim TH, Barrera LO, Zheng M, Qu C, Singer MA, Richmond TA, Wu Y, Green RD, Ren B, Kim TH, Abdullaev ZK, Smith AD, Ching KA, Loukinov DI, Green RD, Zhang MQ, Lobanenkov VV, Ren B, Kouzarides T, Lee YH, Koh SS, Zhang X, Cheng X, Stallcup MR, Lee CK, Shibata Y, Rao B, Strahl BD, Lieb JD, Lee TI, Jenner RG, Boyer LA, Guenther MG, Levine SS, Kumar RM, Chevalier B, Johnstone SE, Cole MF, Isono K, al. et, Liu CL, Kaplan T, Kim M, Buratowski S, Schreiber SL, Friedman N, Rando OJ, Loots GG, Locksley RM, Blankespoor CM, Wang ZE, Miller W, Rubin EM, Frazer KA, Meneghini MD, Wu M, Madhani HD, Miller W, Makova KD, Nekrutenko A, Hardison RC, Mito Y, Henikoff JG, Henikoff S, Okada Y, Feng Q, Lin Y, Jiang Q, Li Y, Coffield VM, Su L, Xu G, Zhang Y, Pennacchio LA, Rubin EM, Peters AH, Kubicek S, Mechtler K, O’Sullivan RJ, Derijck AA, Perez-Burgos L, Kohlmaier A, Opravil S, Tachibana M, Shinkai Y, al. et, Pokholok DK, 
Harbison CT, Levine S, Cole M, Hannett NM, Lee TI, Bell GW, Walker K, Rolfe PA, Herbolsheimer E, al. et, Raisner RM, Hartley PD, Meneghini MD, Bao MZ, Liu CL, Schreiber SL, Rando OJ, Madhani HD, Rangasamy D, Berven L, Ridgway P, Tremethick DJ, Roh TY, Cuddapah S, Zhao K, Roh TY, Ngau WC, Cui K, Landsman D, Zhao K, Roh TY, Cuddapah S, Cui K, Zhao K, Roh TY, Wei G, Farrell CM, Zhao K, Schotta G, Lachner M, Sarma K, Ebert A, Sengupta R, Reuter G, Reinberg D, Jenuwein T, Schubeler D, MacAlpine DM, Scalzo D, Wirbelauer C, Kooperberg C, Leeuwen F van, Gottschling DE, O’Neill LP, Turner BM, Delrow J, al. et, Sekinger EA, Moqtaderi Z, Struhl K, Shnyreva M, Weaver WM, Blanchette M, Taylor SL, Tompa M, Fitzpatrick DR, Wilson CB, Sims JK, Houston SI, Magazinnik T, Rice JC, Squazzo SL, O’Geen H, Komashko VM, Krig SR, Jin VX, Jang SW, Margueron R, Reinberg D, Green R, Farnham PJ, Strahl BD, Grant PA, Briggs SD, Sun ZW, Bone JR, Caldwell JA, Mollah S, Cook RG, Shabanowitz J, Hunt DF, Allis CD, Su Al, Wiltshire T, Batalov S, Lapp H, Ching KA, Block D, Zhang J, Soden R, Hayakawa M, Kreiman G, al. et, Talasz H, Lindner HH, Sarg B, Helliger W, Vakoc CR, Sachdeva MM, Wang H, Blobel GA, Yuan GC, Liu YJ, Dion MF, Slack MD, Wu LF, Altschuler SJ, Rando OJ, Zhang Y, Rowley JD, Zhang J, Zhang L, Coombes KR (2007) High-resolution profiling of histone methylations in the human genome. Cell 129:823-37. doi: 10.1016/j.cell.2007.05.009

Bashtrykov P, Jankevicius G, Smarandache A, Jurkowska RZ, Ragozin S, Jeltsch A (2012) Specificity of Dnmt1 for Methylation of Hemimethylated CpG Sites Resides in Its Catalytic Domain. Chem Biol 19:572-578. doi:

10.1016/J.CHEMBIOL.2012.03.010

Baubec T, Colombo DF, Wirbelauer C, Schmidt J, Burger L, Krebs AR, Akalin A, 
Schübeler D (2015) Genomic profiling of DNA methyltransferases reveals a role for DNMT3B in genic methylation. Nature 520:243-247. doi:

10.1038/nature14176

Baubec T, Ivánek R, Lienert F, Schübeler D (2013) Methylation-Dependent and Independent Genomic Targeting Principles of the MBD Protein Family. Cell 153:480-492. doi: 10.1016/J.CELL.2013.03.011

Baymaz HI, Fournier A, Laget S, Ji Z, Jansen PWTC, Smits AH, Ferry L, Mensinga A, Poser I, Sharrocks A, Defossez P-A, Vermeulen M (2014) MBD5 and MBD6 interact with the human PR-DUB complex through their methyl-CpG-binding domain. Proteomics 14:2179-2189. doi: 10.1002/pmic.201400013

Berkyurek AC, Suetake I, Arita K, Takeshita K, Nakagawa A, Shirakawa M, Tajima S (2014) The DNA methyltransferase Dnmt1 directly interacts with the SET and RING finger-associated (SRA) domain of the multifunctional protein Uhrf1 to facilitate accession of the catalytic center to hemi-methylated DNA. J Biol Chem 289:379-86. doi: 10.1074/jbc.M113.523209

Bestor T, Laudano A, Mattaliano R, Ingram V (1988) Cloning and sequencing of a cDNA encoding DNA methyltransferase of mouse cells. The carboxyl-terminal domain of the mammalian enzymes is related to bacterial restriction methyltransferases. J Mol Biol 203:971-83.

Bird A (2002) DNA methylation patterns and epigenetic memory. Genes Dev 16:621. doi: $10.1101 /$ gad. 947102

Boeke J, Ammerpohl O, Kegel S, Moehren U, Renkawitz R (2000) The Minimal Repression Domain of MBD2b Overlaps with the Methyl-CpG-binding Domain and Binds Directly to Sin3A. J Biol Chem 275:34963-34967. doi: 
10.1074/jbc.M005929200

Bostick M, Kim JK, Estève P-O, Clark A, Pradhan S, Jacobsen SE (2007) UHRF1 plays a role in maintaining DNA methylation in mammalian cells. Science 317:1760-4. doi: 10.1126/science.1147939

Brandeis M, Frank D, Keshet I, Siegfried Z, Mendelsohn M, Names A, Temper V, Razin A, Cedar H (1994) Spl elements protect a CpG island from de novo methylation. Nature 371:435-438. doi: 10.1038/371435a0

Cai Y, Geutjes E-J, de Lint K, Roepman P, Bruurs L, Yu L-R, Wang W, van Blijswijk J, Mohammad H, de Rink I, Bernards R, Baylin SB (2014) The NuRD complex cooperates with DNMTs to maintain silencing of key colorectal tumor suppressor genes. Oncogene 33:2157-2168. doi: 10.1038/onc.2013.178

Chuang LS, Ian HI, Koh TW, Ng HH, Xu G, Li BF (1997) Human DNA-(cytosine-5) methyltransferase-PCNA complex as a target for p21WAF1. Science 277:19962000.

Costa Y, Ding J, Theunissen TW, Faiola F, Hore TA, Shliaha P V., Fidalgo M, Saunders A, Lawrence M, Dietmann S, Das S, Levasseur DN, Li Z, Xu M, Reik W, Silva JCR, Wang J (2013) NANOG-dependent function of TET1 and TET2 in establishment of pluripotency. Nature 495:370-374. doi: 10.1038/nature11925

Daniel JM, Spring CM, Crawford HC, Reynolds AB, Baig A (2002) The p120(ctn)binding partner Kaiso is a bi-modal DNA-binding protein that recognizes both a sequence-specific consensus and methylated CpG dinucleotides. Nucleic Acids Res 30:2911-9.

Deaton AM, Bird A (2011) CpG islands and the regulation of transcription. Genes 
Dev 25:1010-1022. doi: 10.1101/gad.2037511

Denis H, Ndlovu MN, Fuks F (2011) Regulation of mammalian DNA

methyltransferases: a route to new mechanisms. EMBO Rep 12:647-56. doi:

10.1038/embor.2011.110

Dong A, Yoder JA, Zhang X, Zhou L, Bestor TH, Cheng X (2001) Structure of human DNMT2, an enigmatic DNA methyltransferase homolog that displays denaturant-resistant binding to DNA. Nucleic Acids Res 29:439-448. doi: 10.1093/nar/29.2.439

Du Q, Luu P-L, Stirzaker C, Clark SJ (2015) Methyl-CpG-binding domain proteins: readers of the epigenome. Epigenomics 7:1051-1073. doi: 10.2217/epi.15.39

Du Q, Wang Z, Schramm VL (2016) Human DNMT1 transition state structure. Proc Natl Acad Sci U S A 113:2916-21. doi: 10.1073/pnas.1522491113

Filion GJP, Zhenilo S, Salozhin S, Yamada D, Prokhortchouk E, Defossez P-A (2006) A family of human zinc finger proteins that bind methylated DNA and repress transcription. Mol Cell Biol 26:169-81. doi: 10.1128/MCB.26.1.169181.2006

Fujita N, Watanabe S, Ichimura T, Tsuruzoe S, Shinkai Y, Tachibana M, Chiba T, Nakao M (2003) Methyl-CpG binding domain 1 (MBD1) interacts with the Suv39h1-HP1 heterochromatic complex for DNA methylation-based transcriptional repression. J Biol Chem 278:24132-8. doi:

10.1074/jbc.M302283200

Fuks F, Hurd PJ, Deplus R, Kouzarides T (2003) The DNA methyltransferases associate with HP1 and the SUV39H1 histone methyltransferase. Nucleic Acids 
Res 31:2305-12.

Gowher H, Jeltsch A (2001) Enzymatic properties of recombinant Dnmt3a DNA methyltransferase from mouse: the enzyme modifies DNA in a non-processive manner and also methylates non-CpA sites. J Mol Biol 309:1201-1208. doi: 10.1006/jmbi.2001.4710

Guenther MG, Levine SS, Boyer LA, Jaenisch R, Young RA (2007) A Chromatin Landmark and Transcription Initiation at Most Promoters in Human Cells. Cell 130:77-88. doi: 10.1016/j.cell.2007.05.042

Guo F, Li X, Liang D, Li T, Zhu P, Guo H, Wu X, Wen L, Gu T-P, Hu B, Walsh CP, Li J, Tang F, Xu G-L (2014a) Active and passive demethylation of male and female pronuclear DNA in the mammalian zygote. Cell Stem Cell 15:447-459. doi: 10.1016/j.stem.2014.08.003

Guo X, Wang L, Li J, Ding Z, Xiao J, Yin X, He S, Shi P, Dong L, Li G, Tian C, Wang J, Cong Y, Xu Y (2014b) Structural insight into autoinhibition and histone H3induced activation of DNMT3A. Nature 517:640-644. doi: 10.1038/nature13899

Gutierrez-Arcelus M, Lappalainen T, Montgomery SB, Buil A, Ongen H, Yurovsky A, Bryois J, Giger T, Romano L, Planchon A, Falconnet E, Bielser D, Gagnebin M, Padioleau I, Borel C, Letourneau A, Makrythanasis P, Guipponi M, Gehrig C, Antonarakis SE, Dermitzakis ET (2013) Passive and active DNA methylation and the interplay with genetic variation in gene regulation. Elife 2:e00523. doi: 10.7554/eLife.00523

Han L, Lin IG, Hsieh CL (2001) Protein binding protects sites on stable episomes and in the chromosome from de novo methylation. Mol Cell Biol 21:3416-24. doi: 10.1128/MCB.21.10.3416-3424.2001 
Harikrishnan KN, Chow MZ, Baker EK, Pal S, Bassal S, Brasacchio D, Wang L, Craig JM, Jones PL, Sif S, El-Osta A (2005) Brahma links the SWI/SNF chromatin-remodeling complex with MeCP2-dependent transcriptional silencing. Nat Genet 37:254-264. doi: 10.1038/ng1516

Hashimoto H, Liu Y, Upadhyay AK, Chang Y, Howerton SB, Vertino PM, Zhang X, Cheng X (2012) Recognition and potential mechanisms for replication and erasure of cytosine hydroxymethylation. Nucleic Acids Res 40:4841-4849. doi: 10.1093/nar/gks155

He Y-F, Li B-Z, Li Z, Liu P, Wang Y, Tang Q, Ding J, Jia Y, Chen Z, Li L, Sun Y, Li X, Dai Q, Song C-X, Zhang K, He C, Xu G-L (2011) Tet-Mediated Formation of 5Carboxylcytosine and Its Excision by TDG in Mammalian DNA. Science (80- ) 333:1303-1307. doi: 10.1126/science.1210944

Hendrich B, Bird A (1998) Identification and characterization of a family of mammalian methyl-CpG binding proteins. Mol Cell Biol 18:6538-47. doi: 10.1128/MCB.18.11.6538

Hendrich B, Hardeland U, Ng HH, Jiricny J, Bird A (1999) The thymine glycosylase MBD4 can bind to the product of deamination at methylated CpG sites. Nature 401:301-304. doi: 10.1038/45843

Huang Y, Chavez L, Chang X, Wang X, Pastor WA, Kang J, Zepeda-Martínez JA, Pape UJ, Jacobsen SE, Peters B, Rao A (2014) Distinct roles of the methylcytosine oxidases Tet1 and Tet2 in mouse embryonic stem cells. Proc Natl Acad Sci U S A 111:1361-6. doi: 10.1073/pnas.1322921111

Huntriss J, Hinkins M, Oliver B, Harris SE, Beazley JC, Rutherford AJ, Gosden RG, Lanzendorf SE, Picton HM (2004) Expression of mRNAs for DNA 
methyltransferases and methyl-CpG-binding proteins in the human female germ line, preimplantation embryos, and embryonic stem cells. Mol Reprod Dev 67:323-336. doi: $10.1002 / \mathrm{mrd} .20030$

Ito S, D'Alessio AC, Taranova O V, Hong K, Sowers LC, Zhang Y (2010) Role of Tet proteins in $5 \mathrm{mC}$ to $5 \mathrm{hmC}$ conversion, ES-cell self-renewal and inner cell mass specification. Nature 466:1129-33. doi: 10.1038/nature09303

Ito S, Shen L, Dai Q, Wu SC, Collins LB, Swenberg JA, He C, Zhang Y (2011) Tet Proteins Can Convert 5-Methylcytosine to 5-Formylcytosine and 5Carboxylcytosine. Science (80- ) 333:1300-1303. doi: 10.1126/science.1210597

Ji D, Lin K, Song J, Wang Y (2014) Effects of Tet-induced oxidation products of 5methylcytosine on Dnmt1- and DNMT3a-mediated cytosine methylation. Mol Biosyst 10:1749. doi: 10.1039/c4mb00150h

Jia D, Jurkowska RZ, Zhang X, Jeltsch A, Cheng X (2007) Structure of Dnmt3a bound to Dnmt3L suggests a model for de novo DNA methylation. Nature 449:248-251. doi: 10.1038/nature06146

Kadoch C, Crabtree GR (2015) Mammalian SWI/SNF chromatin remodeling complexes and cancer: Mechanistic insights gained from human genomics. Sci Adv 1:e1500447-e1500447. doi: 10.1126/sciadv.1500447

Koh KP, Yabuuchi A, Rao S, Huang Y, Cunniff K, Nardone J, Laiho A, Tahiliani M, Sommer CA, Mostoslavsky G, Lahesmaa R, Orkin SH, Rodig SJ, Daley GQ, Rao A (2011) Tet1 and Tet2 regulate 5-hydroxymethylcytosine production and cell lineage specification in mouse embryonic stem cells. Cell Stem Cell 8:20013. doi: $10.1016 /$ j.stem.2011.01.008 
Kohli RM, Zhang Y (2013) TET enzymes, TDG and the dynamics of DNA demethylation. Nature 502:472-479. doi: 10.1038/nature12750

Kokura K, Kaul SC, Wadhwa R, Nomura T, Khan MM, Shinagawa T, Yasukawa T, Colmenares C, Ishii S (2001) The Ski Protein Family Is Required for MeCP2mediated Transcriptional Repression. J Biol Chem 276:34115-34121. doi: 10.1074/jbc.M105747200

Kriaucionis S, Heintz N (2009) The Nuclear DNA Base 5-Hydroxymethylcytosine Is Present in Purkinje Neurons and the Brain. Science (80- ) 324:929-930. doi: 10.1126/science.1169786

Laget S, Joulie M, Le Masson F, Sasai N, Christians E, Pradhan S, Roberts RJ, Defossez P-A (2010) The Human Proteins MBD5 and MBD6 Associate with Heterochromatin but They Do Not Bind Methylated DNA. PLoS One 5:e11982. doi: 10.1371/journal.pone.0011982

Lander ES, Linton LM, Birren B, Nusbaum C, Zody MC, Baldwin J, Devon K, Dewar K, Doyle M, FitzHugh W, Funke R, Gage D, Harris K, Heaford A, Howland J, Kann L, Lehoczky J, LeVine R, McEwan P, McKernan K, Meldrim J, Mesirov JP, Miranda C, Morris W, Naylor J, Raymond C, Rosetti M, Santos R, Sheridan A, Sougnez C, Stange-Thomann Y, Stojanovic N, Subramanian A, Wyman D, Rogers J, Sulston J, Ainscough R, Beck S, Bentley D, Burton J, Clee C, Carter N, Coulson A, Deadman R, Deloukas P, Dunham A, Dunham I, Durbin R, French L, Grafham D, Gregory S, Hubbard T, Humphray S, Hunt A, Jones M, Lloyd C, McMurray A, Matthews L, Mercer S, Milne S, Mullikin JC, Mungall A, Plumb R, Ross M, Shownkeen R, Sims S, Waterston RH, Wilson RK, Hillier LW, McPherson JD, Marra MA, Mardis ER, Fulton LA, Chinwalla AT, Pepin KH, Gish 
WR, Chissoe SL, Wendl MC, Delehaunty KD, Miner TL, Delehaunty A, Kramer JB, Cook LL, Fulton RS, Johnson DL, Minx PJ, Clifton SW, Hawkins T, Branscomb E, Predki P, Richardson P, Wenning S, Slezak T, Doggett N, Cheng JF, Olsen A, Lucas S, Elkin C, Uberbacher E, Frazier M, Gibbs RA, Muzny DM, Scherer SE, Bouck JB, Sodergren EJ, Worley KC, Rives CM, Gorrell JH, Metzker ML, Naylor SL, Kucherlapati RS, Nelson DL, Weinstock GM, Sakaki Y, Fujiyama A, Hattori M, Yada T, Toyoda A, Itoh T, Kawagoe C, Watanabe H, Totoki Y, Taylor T, Weissenbach J, Heilig R, Saurin W, Artiguenave F, Brottier P, Bruls T, Pelletier E, Robert C, Wincker P, Smith DR, Doucette-Stamm L, Rubenfield M, Weinstock K, Lee HM, Dubois J, Rosenthal A, Platzer M, Nyakatura G, Taudien S, Rump A, Yang H, Yu J, Wang J, Huang G, Gu J, Hood L, Rowen L, Madan A, Qin S, Davis RW, Federspiel NA, Abola AP, Proctor MJ, Myers RM, Schmutz J, Dickson M, Grimwood J, Cox DR, Olson M V, Kaul R, Raymond C, Shimizu N, Kawasaki K, Minoshima S, Evans GA, Athanasiou M, Schultz R, Roe BA, Chen F, Pan H, Ramser J, Lehrach H, Reinhardt R, McCombie WR, de la Bastide M, Dedhia N, Blöcker H, Hornischer K, Nordsiek G, Agarwala R, Aravind L, Bailey JA, Bateman A, Batzoglou S, Birney E, Bork P, Brown DG, Burge CB, Cerutti L, Chen HC, Church D, Clamp M, Copley RR, Doerks T, Eddy SR, Eichler EE, Furey TS, Galagan J, Gilbert JG, Harmon C, Hayashizaki Y, Haussler D, Hermjakob H, Hokamp K, Jang W, Johnson LS, Jones TA, Kasif S, Kaspryzk A, Kennedy S, Kent WJ, Kitts P, Koonin E V, Korf I, Kulp D, Lancet D, Lowe TM, McLysaght A, Mikkelsen T, Moran J V, Mulder N, Pollara VJ, Ponting CP, Schuler G, Schultz J, Slater G, Smit AF, Stupka E, Szustakowki J, Thierry-Mieg D, Thierry-Mieg J, Wagner L, Wallis J, Wheeler R, Williams A, Wolf YI, Wolfe KH, Yang SP, Yeh RF, Collins F, Guyer MS, 
Peterson J, Felsenfeld A, Wetterstrand KA, Patrinos A, Morgan MJ, de Jong P,

Catanese JJ, Osoegawa K, Shizuya H, Choi S, Chen YJ, Szustakowki J,

International Human Genome Sequencing Consortium (2001) Initial sequencing and analysis of the human genome. Nature 409:860-921. doi:

$10.1038 / 35057062$

Laukka T, Mariani CJ, Ihantola T, Cao JZ, Hokkanen J, Kaelin WG, Godley LA, Koivunen P (2016) Fumarate and Succinate Regulate Expression of Hypoxiainducible Genes via TET Enzymes. J Biol Chem 291:4256-65. doi: 10.1074/jbc.M115.688762

Le Guezennec X, Vermeulen M, Brinkman AB, Hoeijmakers WAM, Cohen A, Lasonder E, Stunnenberg HG (2006) MBD2/NuRD and MBD3/NuRD, two distinct complexes with different biochemical and functional properties. Mol Cell Biol 26:843-51. doi: 10.1128/MCB.26.3.843-851.2006

Lee J-H, Park S-J, Nakai K (2017) Differential landscape of non-CpG methylation in embryonic stem cells and neurons caused by DNMT3s. Sci Rep 7:11295. doi: $10.1038 / s 41598-017-11800-1$

Legrand C, Tuorto F, Hartmann M, Liebers R, Jacob D, Helm M, Lyko F (2017) Statistically robust methylation calling for whole-transcriptome bisulfite sequencing reveals distinct methylation patterns for mouse RNAs. Genome Res 27:1589-1596. doi: 10.1101/gr.210666.116

Li E, Bestor TH, Jaenisch R (1992) Targeted mutation of the DNA methyltransferase gene results in embryonic lethality. Cell 69:915-26.

Lin IG, Han L, Taghva A, O’Brien LE, Hsieh C-L (2002) Murine de novo methyltransferase Dnmt3a demonstrates strand asymmetry and site preference 
in the methylation of DNA in vitro. Mol Cell Biol 22:704-23.

Lister R, Pelizzola M, Dowen RH, Hawkins RD, Hon G, Tonti-Filippini J, Nery JR, Lee L, Ye Z, Ngo Q-M, Edsall L, Antosiewicz-Bourget J, Stewart R, Ruotti V, Millar AH, Thomson JA, Ren B, Ecker JR (2009) Human DNA methylomes at base resolution show widespread epigenomic differences. Nature 462:315-22. doi: $10.1038 /$ nature 08514

Lorsbach RB, Moore J, Mathew S, Raimondi SC, Mukatira ST, Downing JR (2003) TET1, a member of a novel protein family, is fused to MLL in acute myeloid leukemia containing the $\mathrm{t}(10 ; 11)(q 22 ; q 23)$. Leukemia 17:637-641. doi: 10.1038/sj.leu.2402834

Losman J-A, Kaelin WG (2013) What a difference a hydroxyl makes: mutant IDH, (R)-2-hydroxyglutarate, and cancer. Genes Dev 27:836-52. doi:

10.1101/gad.217406.113

Lu X, Zhao BS, He C (2015) TET Family Proteins: Oxidation Activity, Interacting Molecules, and Functions in Diseases. Chem Rev 115:2225-2239. doi: $10.1021 /$ cr500470n

Lunyak V V., Burgess R, Prefontaine GG, Nelson C, Sze S-H, Chenoweth J, Schwartz P, Pevzner PA, Glass C, Mandel G, Rosenfeld MG (2002) Corepressor-Dependent Silencing of Chromosomal Regions Encoding Neuronal Genes. Science (80- ) 298:1747-1752. doi: 10.1126/science.1076469

Lyko F (2017) The DNA methyltransferase family: a versatile toolkit for epigenetic regulation. Nat Rev Genet 19:81-92. doi: 10.1038/nrg.2017.80

Lyst MJ, Ekiert R, Ebert DH, Merusi C, Nowak J, Selfridge J, Guy J, Kastan NR, 
Robinson ND, de Lima Alves F, Rappsilber J, Greenberg ME, Bird A (2013) Rett syndrome mutations abolish the interaction of MeCP2 with the NCoR/SMRT corepressor. Nat Neurosci 16:898-902. doi: 10.1038/nn.3434

Macleod D, Charlton J, Mullins J, Bird AP (1994) Sp1 sites in the mouse aprt gene promoter are required to prevent methylation of the $\mathrm{CpG}$ island. Genes Dev 8:2282-92.

Marques CJ, João Pinho M, Carvalho F, Bièche I, Barros A, Sousa M (2011) DNA methylation imprinting marks and DNA methyltransferase expression in human spermatogenic cell stages. Epigenetics 6:1354-1361. doi:

10.4161/epi.6.11.17993

Meissner A, Mikkelsen TS, Gu H, Wernig M, Hanna J, Sivachenko A, Zhang X, Bernstein BE, Nusbaum C, Jaffe DB, Gnirke A, Jaenisch R, Lander ES (2008) Genome-scale DNA methylation maps of pluripotent and differentiated cells. Nature 454:766-770. doi: 10.1038/nature07107

Messerschmidt DM, Knowles BB, Solter D (2014) DNA methylation dynamics during epigenetic reprogramming in the germline and preimplantation embryos. Genes Dev 28:812-28. doi: 10.1101/gad.234294.113

Nan X, Meehan RR, Bird A (1993) Dissection of the methyl-CpG binding domain from the chromosomal protein MeCP2. Nucleic Acids Res 21:4886-4892. doi: 10.1093/nar/21.21.4886

Neri F, Incarnato D, Krepelova A, Rapelli S, Pagnani A, Zecchina R, Parlato C, Oliviero S (2013) Genome-wide analysis identifies a functional association of Tet1 and Polycomb repressive complex 2 in mouse embryonic stem cells. Genome Biol 14:R91. doi: 10.1186/gb-2013-14-8-r91 
$\mathrm{Ng} \mathrm{HH}$, Zhang Y, Hendrich B, Johnson CA, Turner BM, Erdjument-Bromage H, Tempst P, Reinberg D, Bird A (1999) MBD2 is a transcriptional repressor belonging to the MeCP1 histone deacetylase complex. Nat Genet 23:58-61. doi: $10.1038 / 12659$

Ohm JE, McGarvey KM, Yu X, Cheng L, Schuebel KE, Cope L, Mohammad HP, Chen W, Daniel VC, Yu W, Berman DM, Jenuwein T, Pruitt K, Sharkis SJ, Watkins DN, Herman JG, Baylin SB (2007) A stem cell-like chromatin pattern may predispose tumor suppressor genes to DNA hypermethylation and heritable silencing. Nat Genet 39:237-242. doi: 10.1038/ng1972

Okano M, Bell DW, Haber DA, Li E (1999) DNA methyltransferases Dnmt3a and Dnmt3b are essential for de novo methylation and mammalian development. Cell 99:247-257. doi: 10.1016/S0092-8674(00)81656-6

Okano M, Li E, Xie S (1998) Cloning and characterization of a family of novel mammalian DNA (cytosine-5) methyltransferases. Nat Genet 19:219-220. doi: $10.1038 / 890$

Ooi SKT, Qiu C, Bernstein E, Li K, Jia D, Yang Z, Erdjument-Bromage H, Tempst P, Lin S-P, Allis CD, Cheng X, Bestor TH (2007) DNMT3L connects unmethylated lysine 4 of histone $\mathrm{H} 3$ to de novo methylation of DNA. Nature 448:714-717. doi: 10.1038/nature05987

Petronzelli F, Riccio A, Markham GD, Seeholzer SH, Genuardi M, Karbowski M, Yeung AT, Matsumoto Y, Bellacosa A (2000) Investigation of the substrate spectrum of the human mismatch-specific DNA N-glycosylase MED1 (MBD4): fundamental role of the catalytic domain. J Cell Physiol 185:473-80. doi: 10.1002/1097-4652(200012)185:3<473::AID-JCP19>3.0.CO;2-\# 
Prokhortchouk A, Hendrich B, Jørgensen H, Ruzov A, Wilm M, Georgiev G, Bird A, Prokhortchouk E (2001) The p120 catenin partner Kaiso is a DNA methylationdependent transcriptional repressor. Genes Dev 15:1613-8. doi:

10.1101/gad.198501

Ramírez J, Dege C, Kutateladze TG, Hagman J (2012) MBD2 and multiple domains of CHD4 are required for transcriptional repression by Mi-2/NuRD complexes. Mol Cell Biol 32:5078-88. doi: 10.1128/MCB.00819-12

Rollins RA, Haghighi F, Edwards JR, Das R, Zhang MQ, Ju J, Bestor TH (2005) Large-scale structure of genomic methylation patterns. Genome Res 16:157163. doi: $10.1101 /$ gr.4362006

Rountree MR, Bachman KE, Baylin SB (2000) DNMT1 binds HDAC2 and a new corepressor, DMAP1, to form a complex at replication foci. Nat Genet 25:269-277. doi: $10.1038 / 77023$

Saito M, Ishikawa F (2002) The mCpG-binding Domain of Human MBD3 Does Not Bind to mCpG but Interacts with NuRD/Mi2 Components HDAC1 and MTA2. J Biol Chem 277:35434-35439. doi: 10.1074/jbc.M203455200

Sarraf SA, Stancheva I (2004) Methyl-CpG binding protein MBD1 couples histone H3 methylation at lysine 9 by SETDB1 to DNA replication and chromatin assembly. Mol Cell 15:595-605. doi: 10.1016/j.molcel.2004.06.043

Sasai N, Nakao M, Defossez P-A (2010) Sequence-specific recognition of methylated DNA by human zinc-finger proteins. Nucleic Acids Res 38:5015-22. doi: $10.1093 /$ nar/gkq280

Sasaki H, Matsui Y (2008) Epigenetic events in mammalian germ-cell development: 
reprogramming and beyond. Nat Rev Genet 9:129-140. doi: 10.1038/nrg2295

Saxonov S, Berg P, Brutlag DL (2006) A genome-wide analysis of CpG dinucleotides in the human genome distinguishes two distinct classes of promoters. Proc Natl Acad Sci U S A 103:1412-7. doi: 10.1073/pnas.0510310103

Schulz WA, Steinhoff C, Florl AR (2006) Methylation of endogenous human retroelements in health and disease. Curr Top Microbiol Immunol 310:211-50.

Seisenberger S, Andrews S, Krueger F, Arand J, Walter J, Santos F, Popp C, Thienpont B, Dean W, Reik W (2012) The Dynamics of Genome-wide DNA Methylation Reprogramming in Mouse Primordial Germ Cells. Mol Cell 48:849862. doi: 10.1016/j.molcel.2012.11.001

Sharif J, Muto M, Takebayashi S, Suetake I, Iwamatsu A, Endo TA, Shinga J, Mizutani-Koseki Y, Toyoda T, Okamura K, Tajima S, Mitsuya K, Okano M, Koseki H (2007) The SRA protein Np95 mediates epigenetic inheritance by recruiting Dnmt1 to methylated DNA. Nature 450:908-912. doi:

10.1038/nature06397

Shyh-Chang N, Daley GQ, Abbott AL, Alvarez-Saavedra E, Miska EA, Lau NC, Bartel DP, Horvitz HR, Ambros V, Alexander PB, Wang J, McKnight SL, Ambros V, Horvitz HR, Antebi A, Culotti JG, Hedgecock EM, Antebi A, Yeh WH, Tait D, Hedgecock EM, Riddle DL, Balzer E, Moss EG, Balzer E, Heine C, Jiang Q, Lee VM, Moss EG, Barbaux S, Gascoin-Lachambre G, Buffat C, Monnier P, Mondon F, Tonanny MB, Pinard A, Auer J, Bessières B, Barlier A, al. et, Barbieri M, Rizzo MR, Manzella D, Grella R, Ragno E, Carbonella M, Abbatecola AM, Paolisso G, Bartke A, Beachy SH, Onozawa M, Chung YJ, Slape C, Bilke S, Francis P, Pineda M, Walker RL, Meltzer P, Aplan PD, Benhamed M, Herbig U, 
Ye T, Dejean A, Bischof O, Bethke A, Fielenbach N, Wang Z, Mangelsdorf DJ, Antebi A, Bhat-Nakshatri P, Wang G, Collins NR, Thomson MJ, Geistlinger TR, Carroll JS, Brown M, Hammond S, Srour EF, Liu Y, Nakshatri H, Blasco MA, Lee HW, Hande MP, Samper E, Lansdorp PM, DePinho RA, Greider CW, Boiko AD, Razorenova OV, Rijn M van de, Swetter SM, Johnson DL, Ly DP, Butler PD, Yang GP, Joshua B, Kaplan MJ, al. et, Bousquet M, Quelen C, Rosati R, Mas VM-D, Starza R La, Bastard C, Lippert E, Talmant P, Lafage-Pochitaloff M, Leroux D, al. et, Bousquet M, Harris MH, Zhou B, Lodish HF, Boyerinas B, Park SM, Shomron N, Hedegaard MM, Vinther J, Andersen JS, Feig C, Xu J, Burge CB, Peter ME, Buganim Y, Faddah DA, Cheng AW, Itskovich E, Markoulaki S, Ganz K, Klemm SL, Oudenaarden A van, Jaenisch R, Cao D, Liu A, Wang F, Allan RW, Mei K, Peng Y, Du J, Guo S, Abel TW, Lane Z, al. et, Cao D, Allan RW, Cheng L, Peng Y, Guo CC, Dahiya N, Akhi S, Li J, Chalfie M, Horvitz HR, Sulston JE, Chang TC, Zeitels LR, Hwang HW, Chivukula RR, Wentzel EA, Dews M, Jung J, Gao P, Dang CV, Beer MA, al. et, Chang HM, Martinez NJ, Thornton JE, Hagan JP, Nguyen KD, Gregory RI, Chaudhuri AA, So AY, Mehta A, Minisandram A, Sinha N, Jonsson VD, Rao DS, O'Connell RM, Baltimore D, Chawla G, Sokol NS, Chiefari E, Tanyolaç S, Paonessa F, Pullinger CR, Capula C, liritano S, Mazza T, Forlin M, Fusco A, Durlach V, al. et, Cho J, Chang H, Kwon SC, Kim B, Kim Y, Choe J, Ha M, Kim YK, Kim VN, Cox JL, Mallanna SK, Luo X, Rizzino A, Dang CV, Diskin SJ, Capasso M, Schnepp RW, Cole KA, Attiyeh EF, Hou C, Diamond M, Carpenter EL, Winter C, Lee H, al. et, Feng B, Jiang J, Kraus P, Ng JH, Heng JC, Chan YS, Yaw LP, Zhang W, Loh YH, Han J, al. et, Folmes CDL, Nelson TJ, Martinez-Fernandez A, Arrell DK, Lindor JZ, Dzeja PP, Ikeda Y, Perez-Terzic C, Terzic A, Frost RJ, Olson EN, Ge Y, Sun Y, 
Chen J, Gehrke S, Imai Y, Sokol N, Lu B, Gerisch B, Rottiers V, Li D, Motola

DL, Cummins CL, Lehrach H, Mangelsdorf DJ, Antebi A, Gillis AJ, Stoop H,

Biermann K, Gurp RJ van, Swartzman E, Cribbes S, Ferlinz A, Shannon M,

Oosterhuis JW, Looijenga LH, Golipour A, David L, Liu Y, Jayakumaran G,

Hirsch CL, Trcka D, Wrana JL, Guo G, Smith A, Guo Y, Chen Y, Ito H,

Watanabe A, Ge X, Kodama T, Aburatani H, Guo S, Lu J, Schlanger R, Zhang

H, Wang JY, Fox MC, Purton LE, Fleming HH, Cobb B, Merkenschlager M, al.

et, Hafner M, Max KE, Bandaru P, Morozov P, Gerstberger S, Brown M, Molina

H, Tuschl T, Hagan JP, Piskounova E, Gregory RI, Hammell CM, Karp X,

Ambros V, Hanna J, Saha K, Pando B, Zon J van, Lengner CJ, Creyghton MP, Oudenaarden A van, Jaenisch R, Heng JC, Feng B, Han J, Jiang J, Kraus P, Ng JH, Orlov YL, Huss M, Yang L, Lufkin T, al. et, Heo I, Joo C, Cho J, Ha M, Han J, Kim VN, Heo I, Joo C, Kim Y-K, Ha M, Yoon M-J, Cho J, Yeom K-H, Han J, Kim VN, Heo I, Ha M, Lim J, Yoon MJ, Park JE, Kwon SC, Chang H, Kim VN, Horvitz HR, Sulston JE, Iliopoulos D, Hirsch HA, Struhl K, Ishizawa K, Rasheed ZA, Karisch R, Wang Q, Kowalski J, Susky E, Pereira K, Karamboulas C, Moghal N, Rajeshkumar NV, al. et, Jain M, Nilsson R, Sharma S, Madhusudhan N, Kitami T, Souza AL, Kafri R, Kirschner MW, Clish CB, Mootha VK, Janiszewska M, Suvà ML, Riggi N, Houtkooper RH, Auwerx J, ClémentSchatlo V, Radovanovic I, Rheinbay E, Provero P, Stamenkovic I, Jiang X, Huang H, Li Z, Li Y, Wang X, Gurbuxani S, Chen P, He C, You D, Zhang S, al. et, Jin J, Jing W, Lei XX, Feng C, Peng S, Boris-Lawrie K, Huang Y, Johnson SM, Grosshans H, Shingara J, Byrom M, Jarvis R, Cheng A, Labourier E, Reinert KL, Brown D, Slack FJ, Johnson CD, Esquela-Kerscher A, Stefani G, Byrom M, Kelnar K, Ovcharenko D, Wilson M, Wang X, Shelton J, Shingara J, 
al. et, Kawahara H, Okada Y, Imai T, Iwanami A, Mischel PS, Okano H, King

CE, Cuatrecasas M, Castells A, Sepulveda AR, Lee JS, Rustgi AK, Klusmann JH, Li Z, Böhmer K, Maroz A, Koch ML, Emmrich S, Godinho FJ, Orkin SH, Reinhardt D, Kolquist KA, Ellisen LW, Counter CM, Meyerson M, Tan LK, Weinberg RA, Haber DA, Gerald WL, Lagos-Quintana M, Rauhut R, Yalcin A, Meyer J, Lendeckel W, Tuschl T, Le MT, Xie H, Zhou B, Chia PH, Rizk P, Um M, Udolph G, Yang H, Lim B, Lodish HF, Le MT, Teh C, Shyh-Chang N, Xie H, Zhou B, Korzh V, Lodish HF, Lim B, Le MT, Shyh-Chang N, Khaw SL, Chin L, Teh C, Tay J, O’Day E, Korzh V, Yang H, Lal A, al. et, Lee YS, Dutta A, Legesse-Miller A, Elemento O, Pfau SJ, Forman JJ, Tavazoie S, Coller HA, Lehrbach NJ, Armisen J, Lightfoot HL, Murfitt KJ, Bugaut A, Balasubramanian S, Miska EA, Li N, Zhong X, Lin X, Guo J, Zou L, Tanyi JL, Shao Z, Liang S, Wang LP, Hwang WT, al. et, Liau SS, Jazag A, Whang EE, Locasale JW, Grassian AR, Melman T, Lyssiotis CA, Mattaini KR, Bass AJ, Heffron G, Metallo CM, Muranen T, Sharfi H, al. et, Marson A, Levine SS, Cole MF, Frampton GM, Brambrink T, Johnstone S, Guenther MG, Johnston WK, Wernig M, Newman J, al. et, Martello G, Sugimoto T, Diamanti E, Joshi A, Hannah R, Ohtsuka S, Göttgens B, Niwa H, Smith A, Mayr C, Hemann MT, Bartel DP, Melton C, Judson RL, Blelloch R, Molenaar JJ, Domingo-Fernández R, Ebus ME, Lindner S, Koster J, Drabek K, Mestdagh P, Sluis P van, Valentijn LJ, Nes J van, al. et, Morita K, Han M, Moss EG, Tang L, Moss EG, Lee RC, Ambros V, Nam Y, Chen C, Gregory RI, Chou JJ, Sliz P, Newman MA, Thomson JM, Hammond SM, Nichols J, Smith A, Nichols J, Chambers I, Taga T, Smith A, Nishino J, Kim I, Chada K, Morrison SJ, O’Connell RM, Chaudhuri AA, Rao DS, Gibson WSJ, Balazs AB, Baltimore D, Onder TT, Kara N, Cherry A, Sinha AU, Zhu N, Bernt 
KM, Cahan P, Marcarci BO, Unternaehrer J, Gupta PB, al. et, Ooi AG, Sahoo

D, Adorno M, Wang Y, Weissman IL, Park CY, Pasquinelli AE, Reinhart BJ, Slack F, Martindale MQ, Kuroda MI, Maller B, Hayward DC, Ball EE, Degnan B, Müller P, al. et, Peng S, Chen LL, Lei XX, Yang L, Lin H, Carmichael GG, Huang Y, Peter ME, Picard D, Miller S, Hawkins CE, Bouffet E, Rogers HA, Chan TS, Kim SK, Ra YS, Fangusaro J, Korshunov A, al. et, Piskounova E, Polytarchou C, Thornton JE, LaPierre RJ, Pothoulakis C, Hagan JP, Iliopoulos D, Gregory RI, Polesskaya A, Cuvellier S, Naguibneva I, Duquet A, Moss EG, Harel-Bellan A, Possemato R, Marks KM, Shaul YD, Pacold ME, Kim D, Birsoy K, Sethumadhavan S, Woo HK, Jang HG, Jha AK, al. et, Quintana E, Shackleton M, Sabel MS, Fullen DR, Johnson TM, Morrison SJ, Quintana E, Shackleton M, Foster HR, Fullen DR, Sabel MS, Johnson TM, Morrison SJ, Ramachandran R, Fausett BV, Goldman D, Rao S, Lee SY, Gutierrez A, Perrigoue J, Thapa RJ, Tu Z, Jeffers JR, Rhodes M, Anderson S, Oravecz T, al. et, Reinhart BJ, Slack FJ, Basson M, Pasquinelli AE, Bettinger JC, Rougvie AE, Horvitz HR, Ruvkun G, Rodini CO, Suzuki DE, Saba-Silva N, Cappellano A, Souza JES de, Cavalheiro S, Toledo SRC, Okamoto OK, Rosen JM, Jordan CT, Roush S, Slack FJ, Rudolph KL, Chang S, Lee HW, Blasco M, Gottlieb GJ, Greider C, DePinho RA, Rybak A, Fuchs H, Smirnova L, Brandt C, Pohl EE, Nitsch R, Wulczyn FG, Sacco A, Mourkioti F, Tran R, Choi J, Llewellyn M, Kraft P, Shkreli M, Delp S, Pomerantz JH, Artandi SE, Blau HM, Sahin E, Depinho RA, Sampson VB, Rong NH, Han J, Yang Q, Aris V, Soteropoulos P, Petrelli NJ, Dunn SP, Krueger LJ, Sangiao-Alvarellos S, Manfredi-Lozano M, Ruiz-Pino F, Navarro VM, Sánchez-Garrido MA, Leon S, Dieguez C, Cordido F, Matagne V, Dissen GA, al. et, Schaetzlein S, Lucas-Hahn A, Lemme E, Kues WA, Dorsch 
M, Manns MP, Niemann H, Rudolph KL, Schulz C, Paus M, Frey K, Schmid R, Kohl Z, Mennerich D, Winkler J, Gillardon F, Shinoda G, Soysa TY de, Seligson MT, Yabuuchi A, Fujiwara Y, Huang PY, Hagan JP, Gregory RI, Moss EG, Daley GQ, Shyh-Chang N, Zheng Y, Locasale JW, Cantley LC, Shyh-Chang N, Locasale JW, Lyssiotis CA, Zheng Y, Teo RY, Ratanasirintrawoot S, Zhang J, Onder T, Unternaehrer JJ, Zhu H, al. et, Shyh-Chang N, Daley GQ, Cantley LC, Sokol NS, Xu P, Jan YN, Ambros V, Suh N, Baehner L, Moltzahn F, Melton C, Shenoy A, Chen J, Blelloch R, Sulston JE, Horvitz HR, Tang F, Barbacioru C, Bao S, Lee C, Nordman E, Wang X, Lao K, Surani MA, Thomson JM, Newman M, Parker JS, Morin-Kensicki EM, Wright T, Hammond SM, Thornton JE, Chang HM, Piskounova E, Gregory RI, Tyner SD, Venkatachalam S, Choi J, Jones S, Ghebranious N, Igelmann H, Lu X, Soron G, Cooper B, Brayton C, al. et, Vadla B, Kemper K, Alaimo J, Heine C, Moss EG, Wynsberghe PM Van, Kai ZS, Massirer KB, Burton VH, Yeo GW, Pasquinelli AE, Heiden MG Vander, Cantley LC, Thompson CB, Viswanathan SR, Daley GQ, Gregory RI, Viswanathan SR, Powers JT, Einhorn W, Hoshida Y, Ng TL, Toffanin S, O’Sullivan M, Lu J, Phillips LA, Lockhart VL, al. et, Vogt EJ, Meglicki M, Hartung KI, Borsuk E, Behr R, Wang J, Alexander P, Wu L, Hammer R, Cleaver O, McKnight SL, Wang W, Yang J, Liu H, Lu D, Chen X, Zenonos Z, Campos LS, Rad R, Guo G, Zhang S, al. et, West JA, Viswanathan SR, Yabuuchi A, Cunniff K, Takeuchi A, Park IH, Sero JE, Zhu H, Perez-Atayde A, Frazier AL, al. et, Wilbert ML, Huelga SC, Kapeli K, Stark TJ, Liang TY, Chen SX, Yan BY, Nathanson JL, Hutt KR, Lovci MT, al. et, Wulczyn FG, Smirnova L, Rybak A, Brandt C, Kwidzinski E, Ninnemann O, Strehle M, Seiler A, Schumacher S, Nitsch R, Xu B, Zhang K, Huang Y, Xue D, Peng Y, Wang F, Allan RW, Cao D, Yang DH, Moss EG, Yi R, 
Qin Y, Macara IG, Cullen BR, Yilmaz OH, Valdez R, Theisen BK, Guo W,

Ferguson DO, Wu H, Morrison SJ, Yu J, Vodyanik MA, Smuga-Otto K,

Antosiewicz-Bourget J, Frane JL, Tian S, Nie J, Jonsdottir GA, Ruotti V, Stewart

R, al. et, Yu F, Yao H, Zhu P, Zhang X, Pan Q, Gong C, Huang Y, Hu X, Su F, Lieberman J, Song E, Yuan X, Ishibashi S, Hatakeyama S, Saito M, Nakayama J, Nikaido R, Haruyama T, Watanabe Y, Iwata H, lida M, al. et, Yuan J, Nguyen CK, Liu X, Kanellopoulou C, Muljo SA, Zhang L, Stokes N, Polak L, Fuchs E, Zhang J, Khvorostov I, Hong JS, Oktay Y, Vergnes L, Nuebel E, Wahjudi PN, Setoguchi K, Wang G, Do A, al. et, Zhang WC, Shyh-Chang N, Yang H, Rai A, Umashankar S, Ma S, Soh BS, Sun LL, Tai BC, Nga ME, al. et, Zheng K, Wu X, Kaestner KH, Wang PJ, Zhu H, Shah S, Shyh-Chang N, Shinoda G, Einhorn WS, Viswanathan SR, Takeuchi A, Grasemann C, Rinn JL, Lopez MF, al. et, Zhu H, Shyh-Chang N, Segrè AV, Shinoda G, Shah SP, Einhorn WS, Takeuchi A, Engreitz JM, Hagan JP, Kharas MG, Consortium D, Investigators M, al. et (2013) Lin28: primal regulator of growth and metabolism in stem cells. Cell Stem Cell 12:395-406. doi: 10.1016/j.stem.2013.03.005

Smallwood SA, Tomizawa S, Krueger F, Ruf N, Carli N, Segonds-Pichon A, Sato S, Hata K, Andrews SR, Kelsey G (2011) Dynamic CpG island methylation landscape in oocytes and preimplantation embryos. Nat Genet 43:811-814. doi: 10.1038/ng.864

Song J, Teplova M, Ishibe-Murakami S, Patel DJ (2012) Structure-based mechanistic insights into DNMT1-mediated maintenance DNA methylation. Science 335:709-12. doi: 10.1126/science.1214453

Spitz F, Furlong EEM (2012) Transcription factors: from enhancer binding to 
developmental control. Nat Rev Genet 13:613-626. doi: 10.1038/nrg3207

Stewart KR, Veselovska L, Kim J, Huang J, Saadeh H, Tomizawa S, Smallwood SA, Chen T, Kelsey G (2015) Dynamic changes in histone modifications precede de novo DNA methylation in oocytes. Genes Dev 29:2449-2462. doi:

10.1101/gad.271353.115

Suetake I, Hayata D, Tajima S (2006) The Amino-Terminus of Mouse DNA Methyltransferase 1 Forms an Independent Domain and Binds to DNA with the Sequence Involving PCNA Binding Motif. J Biochem 140:763-776. doi: $10.1093 / \mathrm{jb} / \mathrm{mvj} 210$

Taddei A, Maison C, Roche D, Almouzni G (2001) Reversible disruption of pericentric heterochromatin and centromere function by inhibiting deacetylases. Nat Cell Biol 3:114-120. doi: 10.1038/35055010

Tahiliani M, Koh KP, Shen Y, Pastor WA, Bandukwala H, Brudno Y, Agarwal S, lyer LM, Liu DR, Aravind L, Rao A (2009) Conversion of 5-methylcytosine to 5hydroxymethylcytosine in mammalian DNA by MLL partner TET1. Science 324:930-5. doi: 10.1126/science.1170116

Uysal F, Akkoyunlu G, Ozturk S (2015) Dynamic expression of DNA methyltransferases (DNMTs) in oocytes and early embryos. Biochimie 116:103113. doi: 10.1016/j.biochi.2015.06.019

Vakoc CR, Sachdeva MM, Wang H, Blobel GA (2006) Profile of histone lysine methylation across transcribed mammalian chromatin. Mol Cell Biol 26:918595. doi: 10.1128/MCB.01529-06

Vassena R, Dee Schramm R, Latham KE (2005) Species-dependent expression 
patterns of DNA methyltransferase genes in mammalian oocytes and preimplantation embryos. Mol Reprod Dev 72:430-436. doi: 10.1002/mrd.20375

Verdin E, Ott M (2014) 50 years of protein acetylation: from gene regulation to epigenetics, metabolism and beyond. Nat Rev Mol Cell Biol 16:258-264. doi: $10.1038 / \mathrm{nrm} 3931$

Weber AR, Krawczyk C, Robertson AB, Kuśnierczyk A, Vågbø CB, Schuermann D, Klungland A, Schär P (2016) Biochemical reconstitution of TET1-TDG-BERdependent active DNA demethylation reveals a highly coordinated mechanism. Nat Commun 7:10806. doi: 10.1038/ncomms10806

Weber M, Hellmann I, Stadler MB, Ramos L, Pääbo S, Rebhan M, Schübeler D (2007) Distribution, silencing potential and evolutionary impact of promoter DNA methylation in the human genome. Nat Genet 39:457-466. doi: 10.1038/ng1990

Wolffe AP, Wade PA, Gegonne A, Jones PL, Ballestar E, Aubry F (1999) Mi-2 complex couples DNA methylation to chromatin remodelling and histone deacetylation. Nat Genet 23:62-66. doi: 10.1038/12664

Xue Y, Wong J, Moreno GT, Young MK, Côté J, Wang W (1998) NURD, a novel complex with both ATP-dependent chromatin-remodeling and histone deacetylase activities. Mol Cell 2:851-61.

Ziller MJ, Gu H, Müller F, Donaghey J, Tsai LT-Y, Kohlbacher O, De Jager PL, Rosen ED, Bennett DA, Bernstein BE, Gnirke A, Meissner A (2013) Charting a dynamic DNA methylation landscape of the human genome. Nature 500:47781. doi: $10.1038 /$ nature 12433

Ziller MJ, Müller F, Liao J, Zhang Y, Gu H, Bock C, Boyle P, Epstein CB, Bernstein 
BE, Lengauer T, Gnirke A, Meissner A (2011) Genomic distribution and intersample variation of non-CpG methylation across human cell types. PLoS Genet 7:e1002389. doi: 10.1371/journal.pgen.1002389 